by Jacek Gurwin

\title{
Long-term monitoring and GIS based determina- tion of groundwater drought propagation, the Lower Silesia region, SW Poland
}

Wroclaw University, Institute of Geological Sciences, Department of Applied Hydrogeology, Pl. Maxa Borna 9, PL - 50-205 Wroclaw, Poland. E-mail: jacek.gurwin@ing.uni.wroc.pl

Droughts may be caused by both natural and anthropogenic factors and delimitation of them is crucial for identification of exposed areas. This study concentrated on the application of the threshold level method combined with GIS modelling applied to hydrogeological drought characterization. The first step was to define groundwater drought periods and analysis of drought intensity and duration based on long-term monitoring data from points evenly spaced within the study area. Then the distribution of hydrogeological drought intensity was identified combining a geostatistical kriging method with the type of geographical region. Utilizing GIS modelling with integration of several parameters the final map was created showing vulnerability and exposure of the area to hydrogeological drought. Studies indicate that the area most exposed to drought is located in the north eastern part of Lower Silesia being influenced by water abstraction and mining activity as well as drought.

\section{Introduction}

This paper presents the method of groundwater drought analysis basing on long-term groundwater monitoring data within the Lower Silesia region in south-western Poland. The statistical calculations, geostatistical and GIS modelling techniques were involved to find out the distribution of drought periods, drought potential and to generate the final maps of vulnerability and exposure of the area subject to hydrogeological drought (e.g.Villholth et al., 2013). Taking a simplified definition from the USGS web site (http://water.usgs.gov/ ogw/drought/) we can assume that a groundwater drought typically refers to a period of decreased groundwater levels that result in waterrelated problems. The amount of groundwater decline that would be considered a drought varies regionally and locally due to differences in groundwater conditions and groundwater requirements for humans and the environment. A nice example of the response of groundwater systems to extreme drought and to anthropogenic actions like the impoundment of a dam is presented by Dai et al. (2010). One of the newest researches considering the assessment of groundwater resources sustainability under climate change, drought and increased usage was carried out by El-Kadi et al. (2014). While Appleyard and Cook (2009) paid attention to the problem of acidification and base cation depletion exacerbated by drought and groundwater withdrawal in Western Australia.

This paper focuses on the problem of groundwater exploitation and mining drainage influencing decrease of water level during extreme conditions of drought periods taking into account that groundwater is the major source of potable water supply in the study area.

Within the hydrological cycle, groundwater is normally the last to react to a drought situation, unless surface water is mainly fed by groundwater. Also, in deep aquifers the lag between a meteorological and a groundwater drought may amount to months or even years (Tallaksen and van Lanen, Eds., 2004; Calow et al. 1997; Rutulis 1987). That is due to a recharge process by indirect leakage of water to deep horizons from a shallow aquifer that is supplied from precipitation. When a meteorological drought appears as an immediate response in an unconfined aquifer the effects on deep aquifers are far postponed. That is why it is so difficult to establish clear and reliable ways of hydrogeological drought interpretation. It would be important to find out an optimal strategy for identifying relationships between the number of elements affecting the drought and the effective groundwater drought risk estimation, taking into account the deeper usable aquifers. However, it must be considered that in the mountain areas the first shallow aquifer is of high importance as well. Having the results of drought investigation, it is possible to establish some general indicative indicators dependent on frequency of the drought occurrence although this is simplified by the fact that it should be straightforward enough to set-up in practice.

\section{Materials and methods}

\section{Study area}

The study area is located in the south western Poland, in the region of Lower Silesia, occupying a territory administered by the Regional Water Management Board (RWMB) in Wroclaw. The southernmost part is in the Sudety Mountains which are divided into the Sudety Foreland, the Western Sudety, the Central Sudety, and the Eastern Sudety. The massif is approx. $300 \mathrm{~km}$ long and $50 \mathrm{~km}$ wide situated on the Polish-Czech border and the main range trends from NW to SE. It is characterized by a system of long ridges with gentle and flat plateaus and, domed peaks, broken through by valleys. More than 
$35 \%$ of the area is covered by forests. Climatic conditions of the higher regions are cold and windy with high humidity. According to the Climate Atlas of Poland (Lorenc, 2005), developed on the basis of a 30-year data set, the mean annual precipitation at high altitudes over the Sudety Mts. varies from about $1200 \mathrm{~mm}$ to $1400 \mathrm{~mm}$ and decreases to the northeast, while parts of the Sudety Foreland receive less than $700 \mathrm{~mm}$ a year. The mean annual temperature reaches between $2-6{ }^{\circ} \mathrm{C}$.

The Lower Silesia region belongs almost entirely to the Odra River basin and the major rivers that all drain into Odra are as follows: Nysa Luzycka, Bóbr, Bystrzyca and Nysa Klodzka as the left tributaries and Barycz, Widawa and Mala Panew as the right tributaries (Figure 1). The fluvial system is characterized by rapidly rising and high water levels and long dry periods. A spring snow melt in the Sudety Mts. can produce large amounts of runoff causing rapid level rising in the rivers flowing down to the Odra River. On the other hand, during the summer and autumn months, low levels persist for weeks.

The Sudety Mts. form the NE part of the Bohemian Massif, which is part of the crystalline basement of the Central European epi-Variscan platform. Hydrogeological conditions of the area are very complex with variable aquifers due to coexistence of tectonically altered metamorphic and plutonic rocks of the Sudety mountains with a thick series of sedimentary rocks in the plains and foothills. The Sudety hydrogeological sub-region (SS), belonging to the middle Odra region (Paczynski and Sadurski, 2007), includes the main mountain range and western foothills. The southern middle Odra hydrogeological sub-region (SMO-S) covers the central part of the area along banks of the Odra River and lies in majority on the vast plains of two physical-geographical macroregions (Kondracki, 2009) called the Silesian and Silesian-Lusatian Lowlands, but also including the Sudety Foreland, because its morphology and hydrogeological conditions are similar rather to the Silesian Lowland than to the Sudety Mts. From the North, these lowlands are delimited by the Wal Trzebnicki Hills, consisting of chain of moraine hills, which separates this sub-region from the northern middle Odra sub-region $(\mathrm{SMO}-\mathrm{N})$ that covers southern part of the Great Poland Lowland (Figure 1).

Characteristics of usable aquifers vary strongly in the described regions, however groundwater is the dominant source for drinking water. Quaternary aquifers are the most widely and intensively exploited because of good recognition and accessibility. They mainly consist of alluvial sediments in the valleys of the larger rivers; sands and gravels in deep buried valleys; and variable thicknesses within intermoraine areas. Particular attention should be paid to the very important role of the glacial valley flow system in the northern subregion that is characterized by the highest groundwater resources. However, the quality of water within Quaternary strata is heavily dependent on the occurrence of boulder clays in the overburden and the adjoining sediments. These types of water-bearing horizons are pumped mainly by drilled wells. In the mountainous part potable water is also commonly withdrawn by drainage intakes from shallow aquifers associated with the weathering zone of crystalline rocks. The thick complex of Neogenic sedimentary rocks, reaching even 300$600 \mathrm{~m}$ in deep tectonic grabens, is recognized as a dominant groundwater collector in the Sudety Foreland area (Dyjor, 1995; Gurwin, 2010; Gurwin and Lubczynski, 2005; Bochenska et al., 1998). The groundwater is also accumulated in Cretaceous basins consisting of fissured sandstones (in the Sudety region) or limestones and marlstones (in the most eastern part within the Mala Panew River

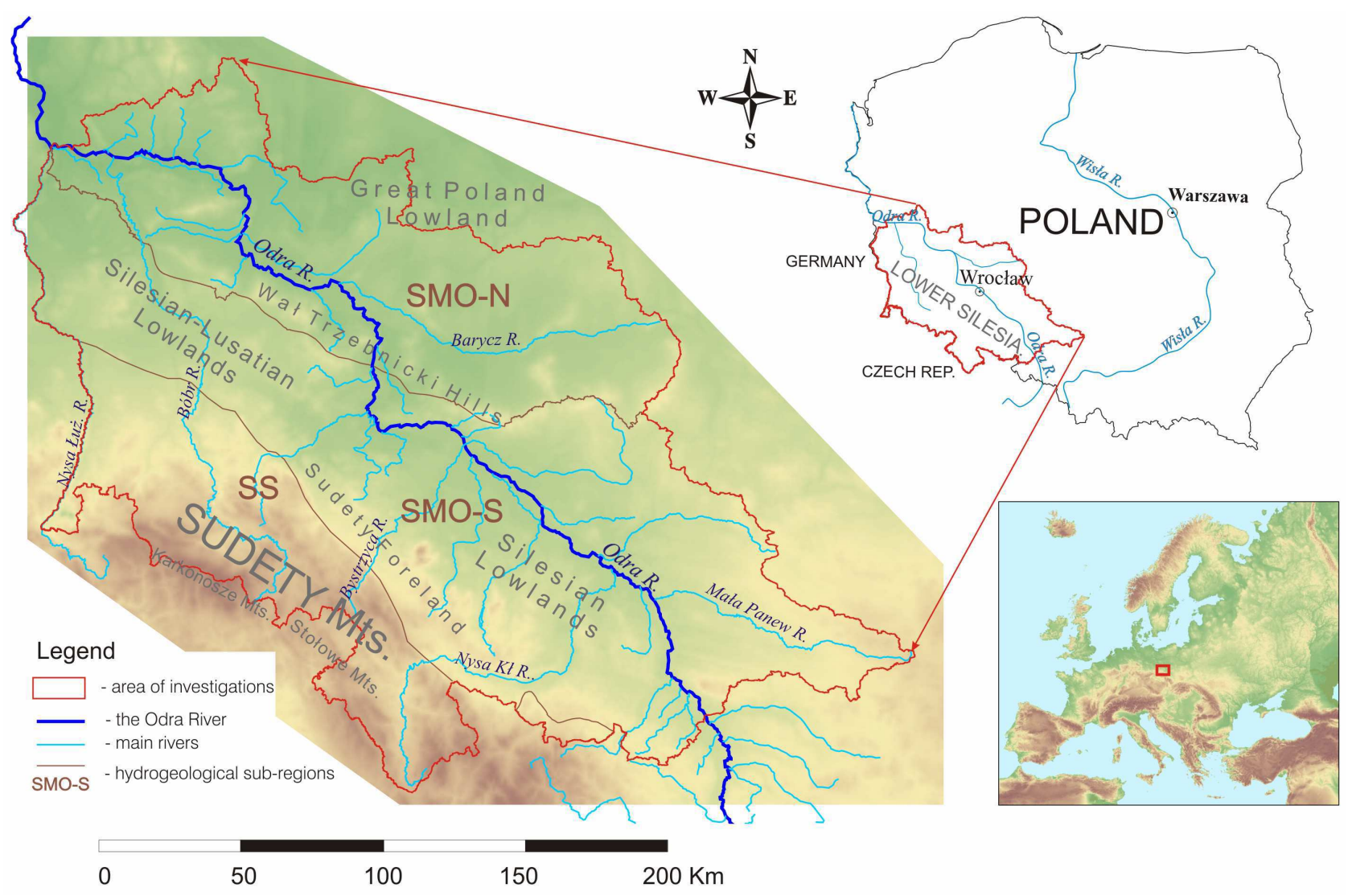

Figure 1. Location of study area. 
catchment) where the flow systems are predominantly associated with fissured porous media and faults.

The Triassic aquifers, including the most important one within karstic limestones of the Late Triassic age, play a crucial role in water supply of the eastern part of the area as well. The total thickness of the Triassic water-bearing complex equals from several meters on the outcrops to $250 \mathrm{~m}$ and the withdrawal from a single well achieves $300 \mathrm{~m}^{3} / \mathrm{h}$ (Stasko, 1992; Kowalczyk, 2003). Due to sufficient quantity and quality of groundwater several major groundwater basins (MGWB) were identified in the region of Lower Silesia within different hydrogeological structures, which were carefully investigated and well documented in many studies. The problems of water management and counteracting the effects of drought within the study area have been the subject of recent investigations (RWMB, 2007; $M G G P$, 2010; Stolarska et al., 2012).

\section{Available monitoring data}

Establishing periods of occurrence, intensity and frequency of hydrogeological drought was conducted on the basis of the interpretation of the long-term groundwater table measurement results. It was based on the data from the National Groundwater Level Archive being compiled by the Polish Hydrogeological Survey. There are 288 monitoring points in the study area, and $85(30 \%)$ out of them control the first water bearing horizon in unconfined conditions and $160(55 \%)$ control deeper confined aquifers. The rest of the monitoring points are springs. The data was verified firstly due to the length of observations, secondly because of representativeness for a particular subarea and in terms of potential influence of artificial drainage. The data cover different periods of time, which can be roughly divided into the following:

starting from 1975-79 r. - 3\% (operating until 2011: 4 points) starting from 1980-84 r. - 1\% (operating until 2011: 3 points) starting from 1985-89 r. - 46.2\% (operating until 2011: 50 points) starting from 1990-94 r. - 4.1\% (operating until 2011: 5 points) starting from 1995-99 r. - 9.1\% (operating until 2011: 13 points) starting from 2000-05 r. - 20,1\% (operating until 2011: 47 points) starting after 2005 r. $\quad-16,5 \%$.

A detailed analysis of changes in groundwater levels within the Middle Odra Region was presented by Stasko et al. (2005). A large number of points apply to new locations where observations are carried out only from the years 2000-2005 or later and those could not be considered in drought analysis. Such a short period of observation is not reliable. So, the final the database used for calculation consists of 77 monitoring points. The distribution of piezometers in the study area is shown in Fig. 6. All of them anchored in usable aquifers can be regarded as representative for the major hydrogeological structures. Therefore this research refers to the risk of depletion of the strategic regional groundwater resources rather than to the influence on the shallow aquifers which are certainly much more vulnerable to the effects of drought.

\section{Derivation of drought duration}

An estimation of groundwater drought based on analysis of the position of the water table is an efficient method because the basis for evaluation is not a set number of indicators but one most important hydrogeological indicator only (Kazimierski et al., 2009). Radfar et al. (2013) point-out that long-term fluctuation studies can help in managing the available water resources and to protect from drought or decrease its negative impact. According to Peters (2003) we can assume that the derivation of the drought events from the relevant time series is a key step in any analysis, as the results may depend strongly on the drought event definition used. Two well-known methods, which can be used to derive drought events from time series such as groundwater recharge, levels and discharge are: the annual minimum approach and the threshold level approach (Peters, 2003). In the first method, a time series is divided in annual periods and for each annual period the minimum is selected (Annual Minimum Series - AMS). Hence, the drought has no duration and multi-year droughts (droughts lasting more than one year) are not possible. The second method is the threshold level approach called the Partial Duration Series (PDS) (Rice, 1954; Cramer and Leadbetter, 1967; Bras and Rodriguez-Iturbe, 1985). The threshold for defining the droughts can be derived in many different ways. The method, which is used most frequently, is to derive the threshold from exceedance probabilities. Commonly used thresholds range from the 50 to the 95 -percentile. In most drought analyses a relative threshold is used, because drought is a deviation from normal conditions (Peters, 2003) (Figure 2). A spatial extent of groundwater droughts for different threshold levels of mean groundwater level is presented for example by Shahid and Hazarika (2010).

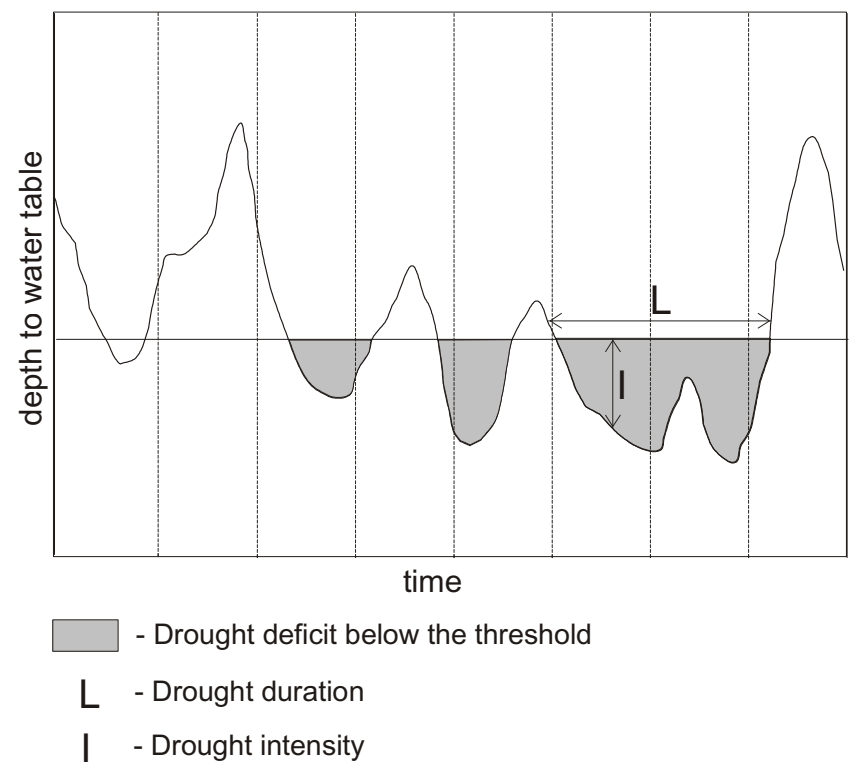

Figure 2. Defining drought events with Partial Duration Series (after Peters, 2003 modified).

In this study groundwater level data were taken to define groundwater drought periods by establishing the periods when the negative deviation of the moving average values in the analyzing period was higher than $50 \%$ of standard deviation. Such a concept was proposed by Stasko et al. (2008) and Tarka and Stasko (2010) for the Sudety Mts. area. The threshold levels were developed using appropriate graphs for monitoring points with had sufficient length of observations.

Then, the difference between moving averages and the average value for the entire period of observation was calculated. In addition, to compare the obtained deviations between the different points of observation, it was divided by the standard deviation value. 


\section{GIS spatial modelling}

A composite mapping analysis technique in a GIS environment is widely used in groundwater studies (e.g. Andreo et al., 2008; Münch and Conrad, 2007; Gurwin, 2010 and many others). A groundwater drought risk assessment utilizing GIS spatial modelling has been developed in several investigations considering the combined physical risk and human groundwater drought vulnerability (MacDonald et al., 2009; Villholth et al., 2013). A spatial distribution of several important factors that determine the exposure, sensitivity and vulnerability to hydrogeological drought was obtained. Due to the fact that a GIS analysis is always associated with an extensive demand for data the goal was to find out an optimal strategy of implementing an effective tool utilizing available data rationally and obtaining credible results. The calculations were done using the ArcGIS Spatial Analyst and ModelBuilder module to integrate the input parameters. The following thematic layers were taken as the input data sets for the GIS model: (1) occurrence of droughts, (OD) (2) distribution of geographical zones (GZ), (3) groundwater resources reserves with respect to actual exploitation (GWE), (4) groundwater resources reserves with respect to exploitation on the level of water permits (GWP), (5) actual exploitation in the water intakes (GWA), (6) drainage impact associated with mining activities (DR). The first two layers make it possible to analyze the vulnerability of the area to the occurrence of hydrogeological drought. The next three layers consider a human activity and, after combining them with the previous two layers, they were used to identify the areas in which it may be the case of a shortage in groundwater resources. That took place in circumstances where a reduction of the water table level due to pumping in wells was observed. Imposing then the last layer allows verification of the results due to the impact of mining drainage.

\section{The components of groundwater use influencing hydrogeological drought}

Permitted groundwater use in this area is predominantly for supplying the population (about $96 \%$ ), use by the industry is at $2 \%$, while that for public institutions accounts for about $1.5 \%$, and agriculture $<1 \%$.

Most groundwater intakes are located in aquifers occurring in the Cenozoic formations, mainly from the Quaternary aquifers (529 intakes) and Neogene-Paleogene aquifers (186 intakes). Water from Triassic aquifers is recognized in 67 intakes. An average daily withdrawal in the area administered by the Regional Water Management Board (RWMB) in Wroclaw is $634 \mathrm{~m}^{3} / \mathrm{d}$. The total groundwater consumption recorded for the Lower Silesia region in 2000-2005 is in the range of 85-90 million $\mathrm{m}^{3}$ and for the RWMB Wroclaw (Water region of Middle Odra) the quantity of 200 million $\mathrm{m}^{3}$ (range 198-208 million $\mathrm{m}^{3}$ ) for the period 2000-2005 was established (Frankowski et al., 2007, 2009). According to more recent data (RWMB Report, 2007) a recorded exploitation for the RWMB region was similar and amounted to 214,4 million $\mathrm{m}^{3}$ per year. Permitted water abstraction is also undertaken for mine dewatering, thermal and medicinal waters, and dewatering of building foundations. Mine drainage is, importantly, related to lignite opencast mining (the "Turów" mine) (Dubicki et al., 2010) or mining of rock (Tarnow Opolski, Strzelce Opolskie, Górazdze and Gogolin) as well as deep copper ore mining (KGHM mines).

Groundwater consumption also occurs from unpermitted exploitation as well as illegal use. Consumption is allowed under the small-scale normal use of water (up to $5 \mathrm{~m}^{3} / \mathrm{d}$ ) but that can only be roughly assessed. The quantity of such a normal water use for the Lower Silesia region was estimated at 28 million $\mathrm{m}^{3}$ or about $30 \%$ of the total recorded consumption (Frankowski et al., 2009; Wojtkowiak et al., 2008; $R W M B, 2007)$. All the factors mentioned above play the role in establishing hydrogeological drought conditions in the region.

The whole area was divided into Groundwater Bodies (GWB) according to the national water management outlines. The location and the number of a particular GWB are shown in the figures below (Figures 6,8). A separate investigation was conducted to establish groundwater resources reserves in comparison with exploitation level in every GWB. Actual exploitation was expressed in terms of the total pumping rate per sq. $\mathrm{km}$.

\section{Results and discussion}

An analysis of the effect of climate change on the groundwater system can be found in the paper of Woldeamlak et al. (2007) taking into account that an appearance of drought may be treated as a succession of climatic disturbances. After Allen et al., (2004), Apaydin (2010), Loáiciga (2003), Okkonen et al., (2010), Radhakrishnan and Elango (2011) or Buczynski and Wcislo (2013), it is evident that climate change may have a negative impact on groundwater resources and shallow aquifers are more susceptible to changes in resources and fluctuations of the groundwater table. These studies also proved that shallow aquifers are affected by local climate changes, whereas deep aquifers are affected only by regional changes. However, the research aims primarily to investigate the impact on groundwater resources of regional importance.

\section{Identifying periods of drought and analysis of its intensity and duration}

Within the group of observation points, and using the longest series of data, there is a clear relationship between the number of observations below a low mean groundwater level (SNG) and the depth of aquifer (Figure 3). These confirm a general tendency that in deep aquifers dry seasons and drought periods persist for long time, even over several seasons. Because several observation points are springs, a low mean discharge (SNQ) is used in interpreting the results.

These results show (Figure 4), that the number of observations of groundwater level or spring discharge, below SNG / SNQ, enables the identification of four basic intervals which clearly show the degree of susceptibility to the occurrence of hydrogeological drought. These demonstrate that: low susceptibility $1-10 \%$, moderate susceptibility $10-20 \%$, high susceptibility $20-30 \%$ very high susceptibility $>30 \%$.

Calculations indicate that, in the area supervised by the Regional Water Management Board (RWMB) in Wroclaw, several specific time intervals can be designated that correspond to a long-term hydrogeological drought. However, depending on the sub-area and type of aquifer, there are significant shifts of these periods (Figure 5). In general, we can distinguish three characteristic periods:

- from autumn 1982 to spring 1984;

- from summer 1990 to spring 1994 (or from summer 1989);

- from summer 2003 to spring 2007.

In addition, some shorter periods with lesser influence, can be distinguished within the season 1982-1983, from autumn 2000 to 


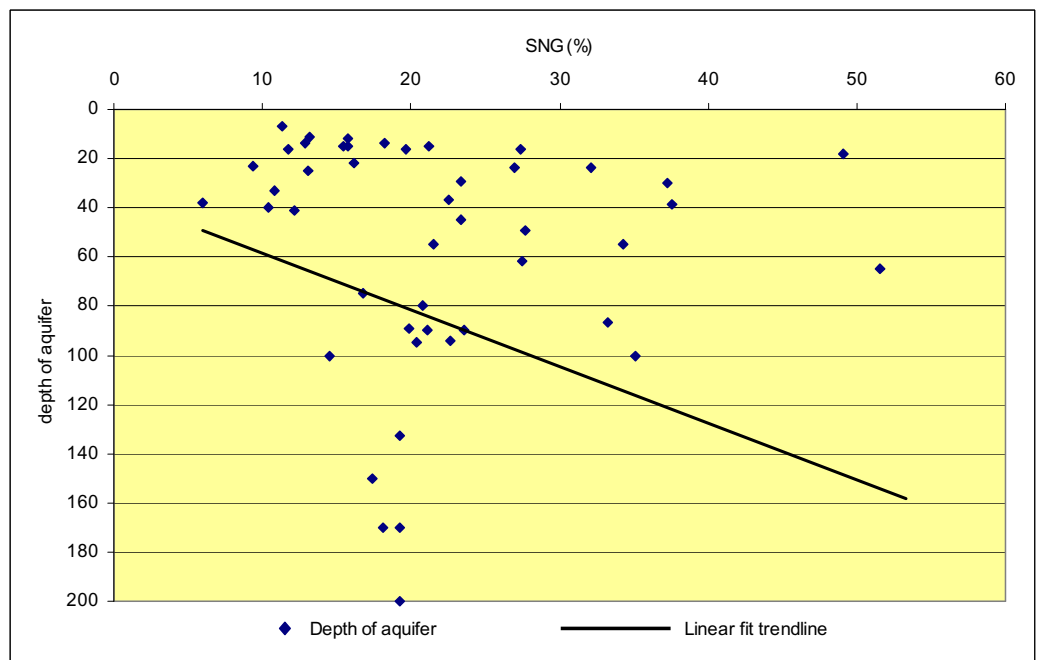

Figure 3. Relationship between the number of observations below a low mean groundwater level (SNG) and the depth of aquifer.

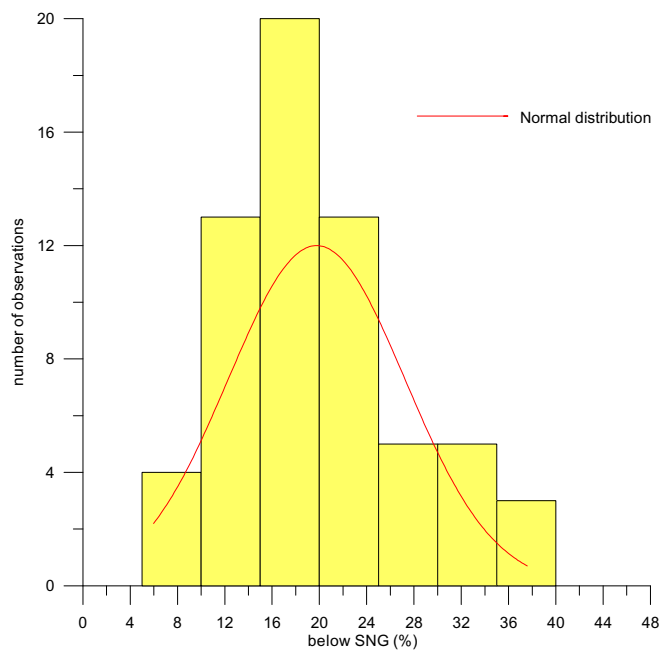

Figure 4. Distribution of observations below a low mean groundwater level (SNG). spring 2002 and in the season 2008-2009 that are particularly evident in shallow aquifer.

The method used can therefore be used for determining the periods of drought, and to indicate what is the percentage of time of it occupied in a multi-year period.

Periods of drought in most of the monitoring points $(65 \%)$ were in the range $20-35 \%$ and these should be regarded as the most authoritative and reliable for the entire study area (Figure 6). However, in the Sudety Mts., the values have a wide range from a few percent to $30 \%$ and the observation point II/ $607 / 1$ is classified as exceeding

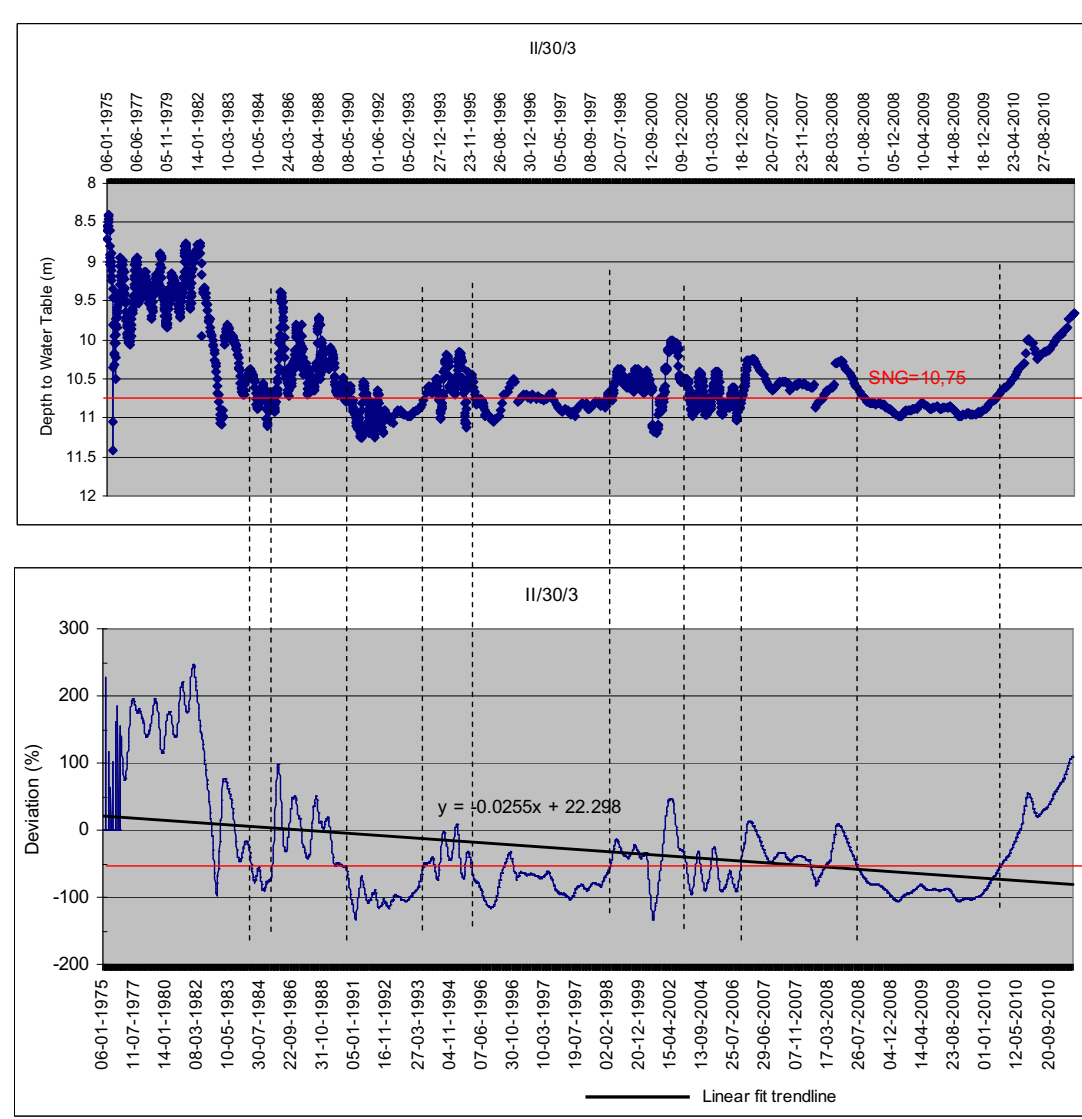

Figure 5. Example of hydrogeological drought period interpretation (monitoring point II/30/3).
$40 \%$ which, in turn, is related to the fact that the observations are associated with the source originating from the fissured sandstone massive of the Stolowe Mts. On the other hand, more favorable conditions in the central part of the study area may be related to the stabilizing role of the Odra valley as a regional base of drainage. The present analysis demonstrates that the most reliable data on hydrogeological drought is obtained from data sequences lasting at least 25-30 years. Over such a long period at least 3-4 droughts occur allowing more reliable evaluation.

Point values were converted, for spatial interpretation, using the geostatistical kriging method (Brooker, 1979) . Extreme values were removed to allow a more complete analysis of hydrogeological drought. The advantage of this method is that during interpolation kriging uses weights from a semivariogram that was developed from surrounding measured values to predict values at unmeasured locations (Isaaks and Srivastava 1988, 1989; Kitanidis, 1997) to obtain a map of the occurrence of hydrogeological drought periods. Taking into account that the drought is highly dependent on morphological, topographical and meteorological conditions of a particular region, the study area was divided according to major geographic units (Figure 7). Afterwards the contour map of drought was combined utilizing GIS tools with a numerical layer of the type of geographical region. Finally, the distribution of hydrogeological drought intensity was identified. After a reclassifying process, 5 classes were developed (Figure 8).

\section{Areas vulnerable to the effects of hydrogeological droughts}

GIS spatial modelling tools allowed the researchers to use a weighted overlay technique combining several parameters with influence factors for each parameter (Table 1). After processing the raster images and resampling to $1 \mathrm{x} 1 \mathrm{~km}$ grid the reclassification of selected layers was carried out to apply rating values in the sixpoint scale (Figure 9). Then, a corresponding weight factor was given to each layer according to the influence 
Table 1. GIS model weighted overlay function parameters

\begin{tabular}{|c|c|c|c|}
\hline Parameter & $\begin{array}{l}\text { Parameter } \\
\text { values }\end{array}$ & Rating & $\begin{array}{c}\text { Weight } \\
\text { factor }(\%)\end{array}$ \\
\hline $\begin{array}{l}\text { Occurrence of droughts } \\
(\mathrm{OD})(\text { in } \%)\end{array}$ & $\begin{array}{l}5-15 \\
>15-20 \\
>20-25 \\
>25-30 \\
>30-35 \\
>35-50\end{array}$ & $\begin{array}{l}6 \\
5 \\
4 \\
3 \\
2 \\
1\end{array}$ & 50 \\
\hline Geographical zones (GZ) & $\begin{array}{l}\text { Mountains } \\
\text { River Valley } \\
\text { Foothills } \\
\text { Hills } \\
\text { Ice-marginal hills } \\
\text { Uplands \& Plains } \\
\text { Plains }\end{array}$ & $\begin{array}{l}6 \\
5 \\
5 \\
4 \\
3 \\
2 \\
1\end{array}$ & 20 \\
\hline $\begin{array}{l}\text { Groundwater resources } \\
\text { reserves with respect to } \\
\text { actual exploitation (GWE) }\end{array}$ & $\begin{array}{l}\text { Very high } \\
\text { High } \\
\text { Medium } \\
\text { Low } \\
\text { Very low } \\
\text { Below limit } \\
\end{array}$ & $\begin{array}{l}6 \\
5 \\
4 \\
3 \\
2 \\
0\end{array}$ & 10 \\
\hline $\begin{array}{l}\text { Groundwater resources } \\
\text { reserves with respect to } \\
\text { exploitation on the level } \\
\text { of water permits (GWP) }\end{array}$ & $\begin{array}{l}\text { Very high } \\
\text { High } \\
\text { Medium } \\
\text { Low } \\
\text { Very low } \\
\text { Below limit } \\
\end{array}$ & $\begin{array}{l}6 \\
5 \\
4 \\
3 \\
2 \\
0\end{array}$ & 5 \\
\hline $\begin{array}{l}\text { Actual exploitation in } \\
\text { the water intakes (GWA) } \\
\left(\text { in } \mathrm{m}^{3} / \mathrm{d}^{*} \mathrm{~km}^{2} \text { ) }\right.\end{array}$ & $\begin{array}{l}0-6 \\
6-12 \\
12-20 \\
20-40 \\
40-67 \\
>67 \\
\text { No } \\
\text { Yes }\end{array}$ & $\begin{array}{l}6 \\
5 \\
4 \\
3 \\
2 \\
1 \\
6 \\
1\end{array}$ & 5 \\
\hline $\begin{array}{l}\text { Drainage impact associated } \\
\text { with mining activities (DR) }\end{array}$ & & & 10 \\
\hline
\end{tabular}

Table 2. Classification of areas according to the severity of the hydrogeological drought

\begin{tabular}{|c|l|l|}
\hline I & The highest degree of risk & Areas strongly affected by drought \\
\hline II & High degree of risk & Areas affected by drought \\
\hline III & Moderate degree of risk & Areas intermediately affected by drought \\
\hline IV & Lowest degree of risk & Areas slightly and weakly affected by drought \\
\hline
\end{tabular}

of particular elements on risk and vulnerability of the area to hydrogeological drought (Table 1). After testing of several models the following weighting parameters were found out: 1/ (OD) $-50 \%$ $2 /(\mathrm{DGZ})-20 \% 3 /(\mathrm{GWE})-10 \%$ 4/ (GWP) - 5\% 5/ (GWA) - 5\% $6 /(\mathrm{DR})-10 \%$. The results of calculations are presented in the map in the 5-point scale (Figure 10).

After additional reclassification, a division into four levels of drought risk within the area was finally accepted (Table 2)

Earlier findings from reports $(R W M B, 2007)$ about high vulnerability to drought of the Barycz river catchment $\left(\mathrm{GWBs} \mathrm{N}^{\mathrm{o}} 79\right.$ and 80 ) were confirmed. Such conditions take place because the area is characterized by low water retention, rapid snowmelt water runoff and lack of water in the summer, and is exposed to a widely expanded drainage system. Similar highly vulnerable conditions were developed for the area to the East of the Odra River valley and within the southeastern part, especially in the Mala Panew river catchment (GWB N ${ }^{\circ}$ 110), where the intensity of the drought impose a high groundwater withdrawal and drainage associated with intensive mining exploitation. In the central and northern parts of the area, along the Odra River valley and on plains and uplands, dominant conditions of moderate vulnerability and exposure to hydrogeological drought are combined with a moderate degree of risk of being affected by drought. Weakly susceptible territory is located in the south-west of the area, in the Sudety Mts. and foreland region (Figure 10, Table 2).

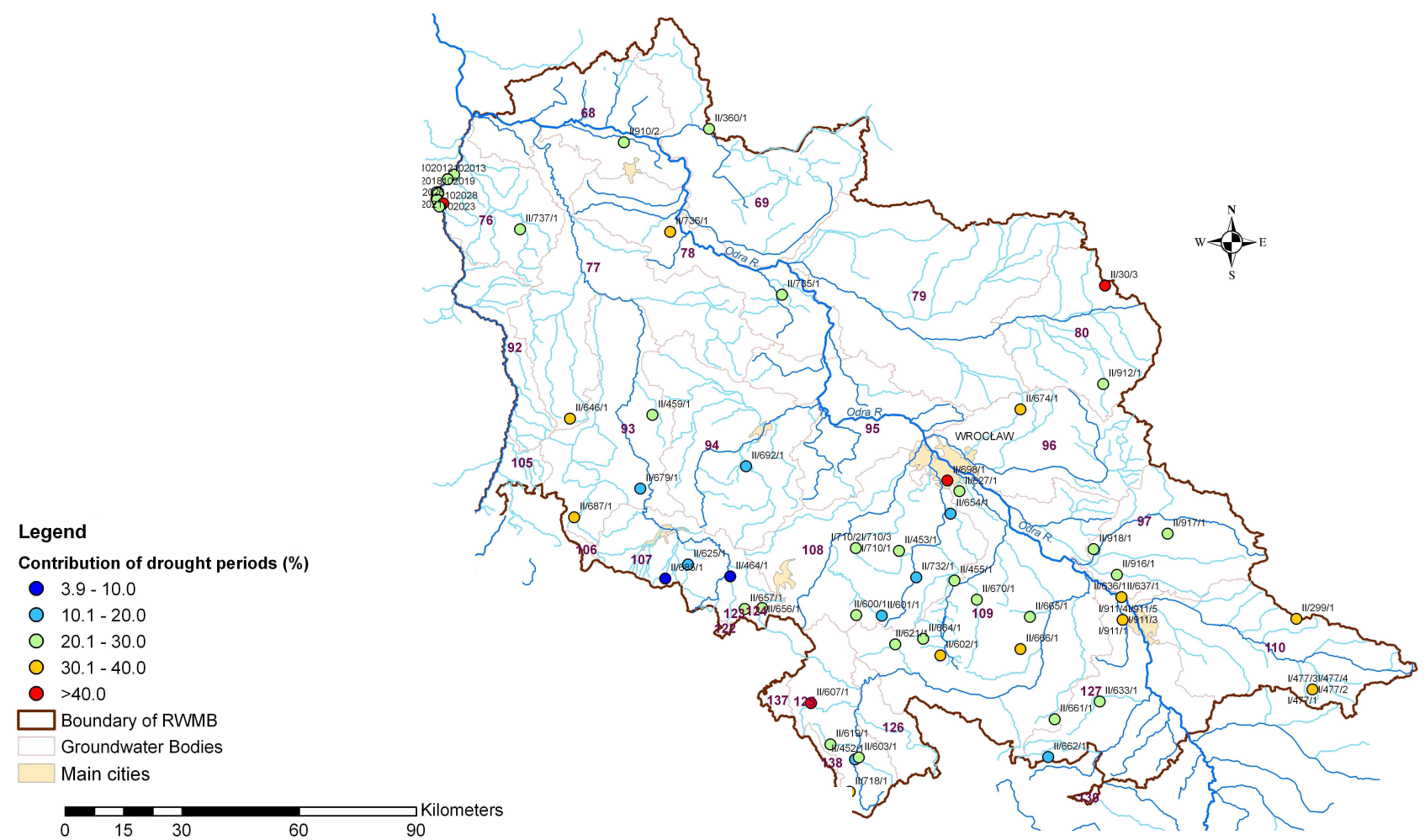

Figure 6. Distribution of hydrogeological drought during a multi-year period after groundwater level data interpretation in monitoring points. 


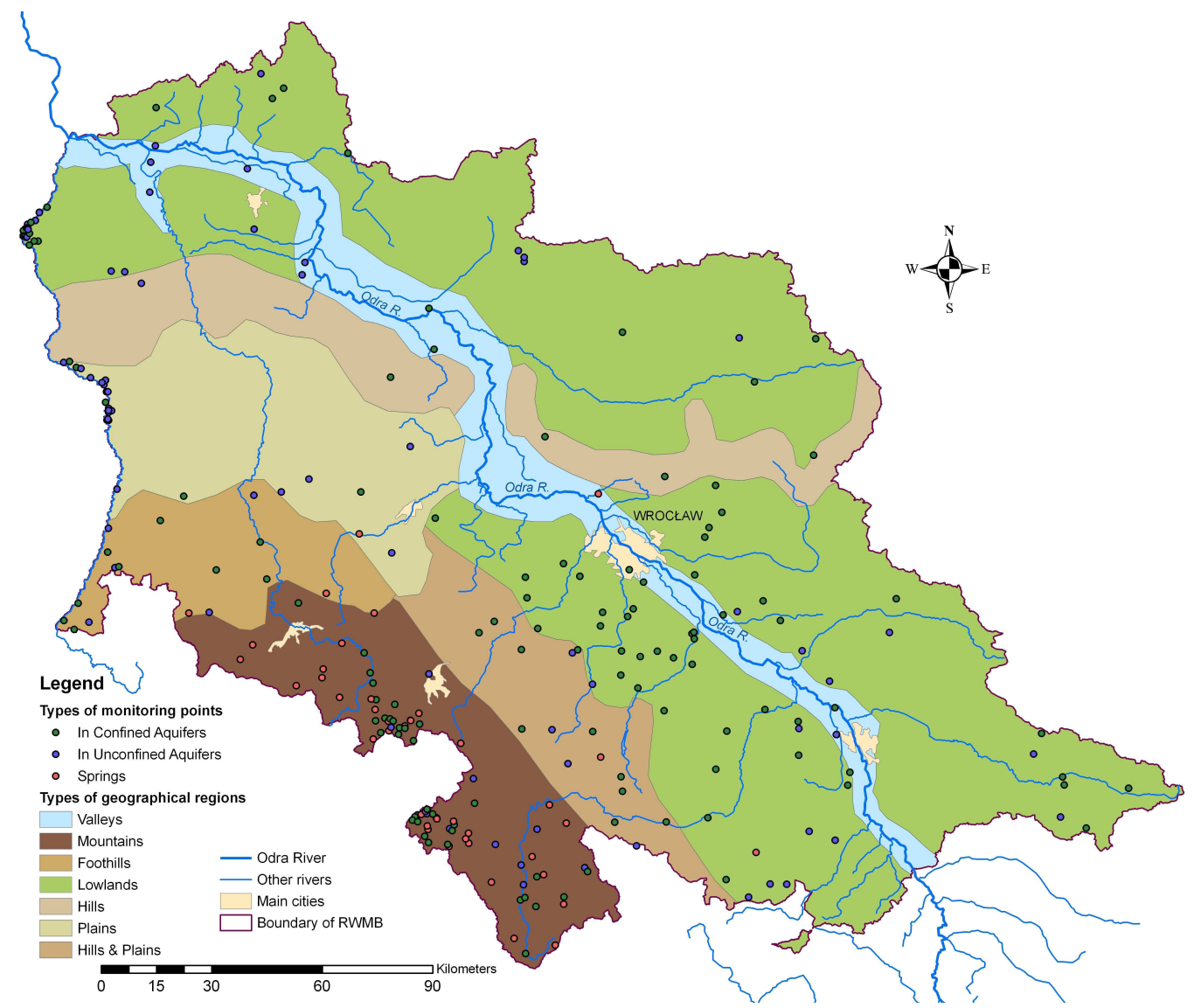

Figure 7. Distribution of monitoring points against the types of geographical regions.

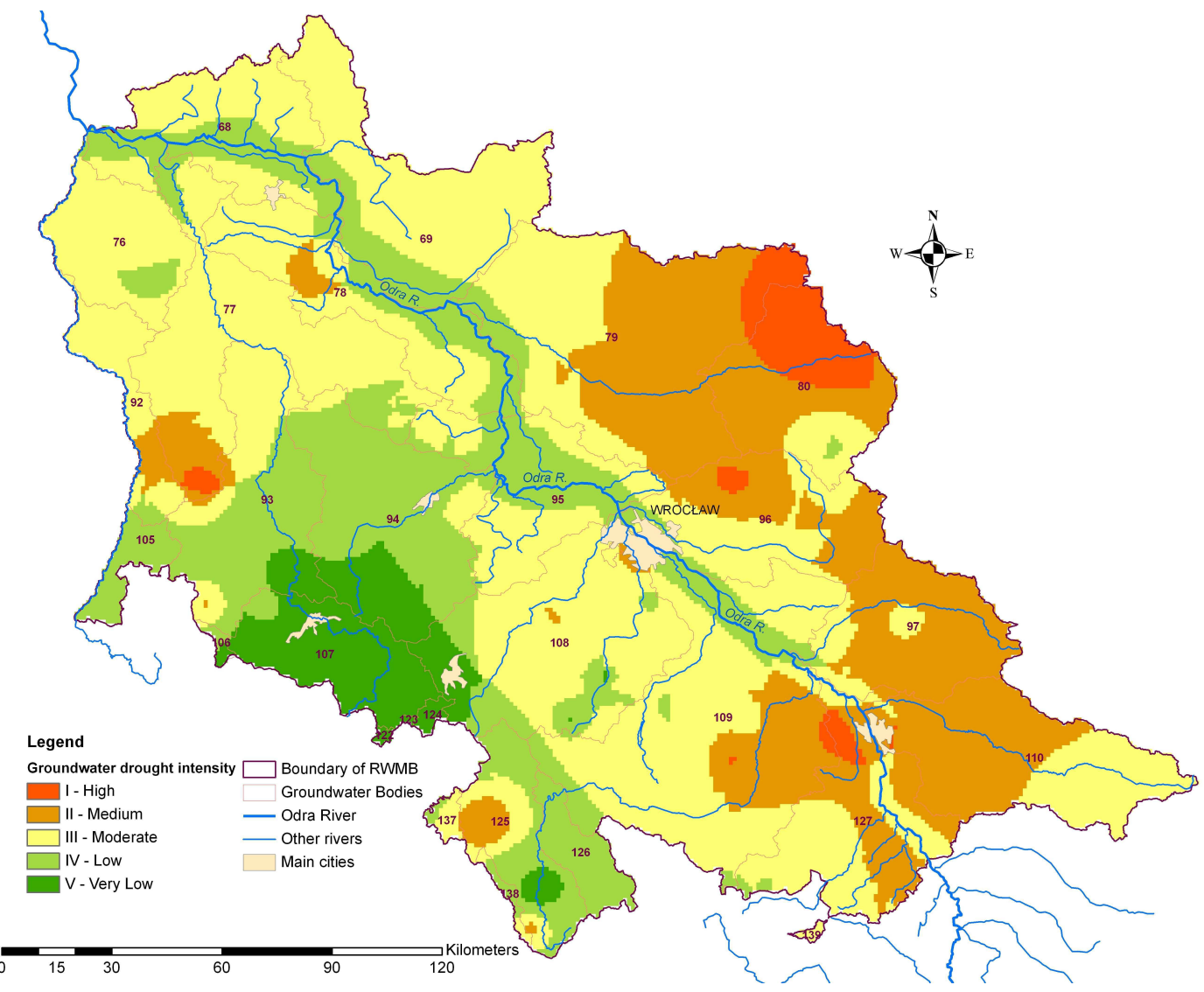

Figure 8. Distribution of groundwater drought intensity. 


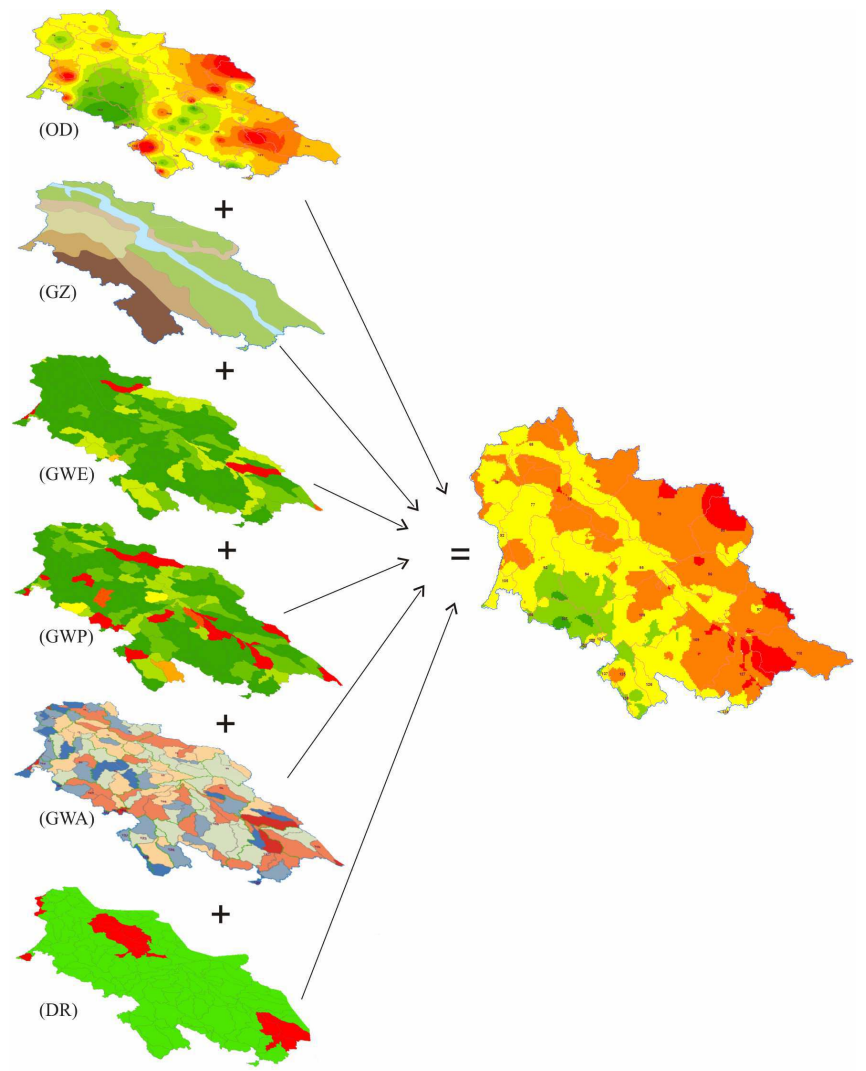

Figure 9. Numerical layers used in spatial GIS modelling for classifying vulnerability to hydrogeological drought.

\section{Conclusions}

A hydrogeological drought determination utilizing long-term monitoring data and GIS modelling is an adequate method even taking into account all necessary generalizations. Groundwater drought in the middle Odra River basin occurs in long periods for several months or extends over several seasons. Because of the widespread withdrawal of groundwater for water supply, the present study focused on the impact of drought on the abundance of usable aquifers, which are covered by the national permitting arrangements and monitoring network. It should be noted that only long-term lack of recharge from infiltration leads to reductions in groundwater resources but their restoration requires long and abundant rainfall and, especially, snowfall. However, the large inertia of these phenomena, the extension in time and confined nature of usable aquifers result in conditions that, even in a drought lasting for several months, does not significantly affect the disposable resources of groundwater or negative effects on the intakes.

The final classification according to the severity of the hydrogeological drought indicates that the areas most affected by drought are located in the northern and south eastern part of the region. In the central part a moderate degree of risk of drought prevails. The highest mountain area, in the south western part of study area, can be considered as only slightly affected by hydrogeological drought.

Taking into account the variability of spring discharge, it should be emphasized that the severity of drought can affect the abundance of the shallow near the surface aquifer, which is often the main source of water in the mountain areas (drainage water intakes). Although these areas have not been identified everywhere as being vulnerable

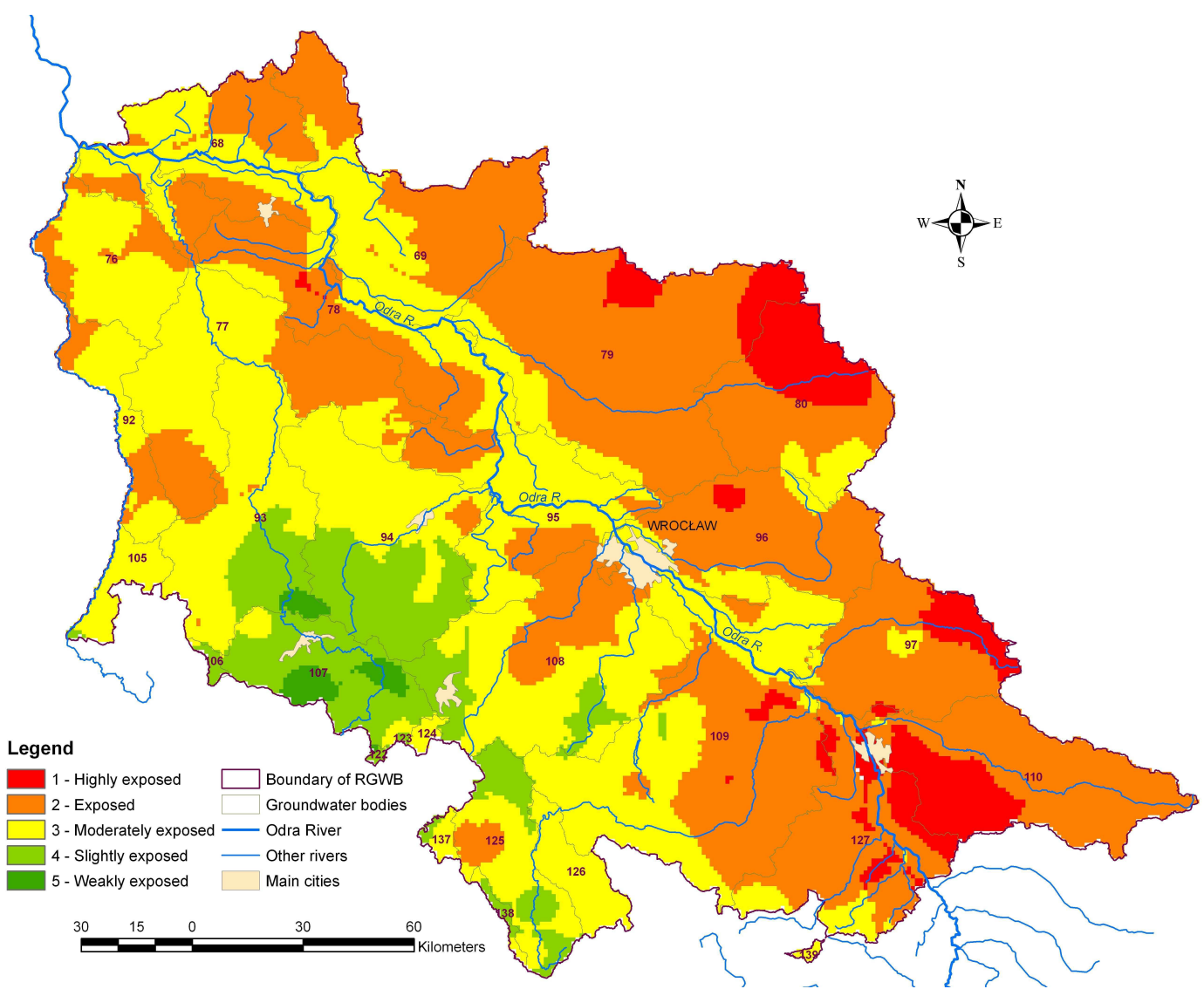

Figure 10. Map showing vulnerability and exposure of the area to hydrogeological drought. 
to drought, compared with the entire region, this issue should be considered very carefully.

Establishing indicative indicators of hydrogeological drought must be linked to the frequency of the occurrence of the states below the identified threshold level. The points with the longest follow-up intervals should be considered as representative, with the exception of border monitoring points exposed to the direct impact of mine drainage. The values of SNG determined for the points can be taken in the current risk assessment, but should be subject to review at least every 5 years. Analysis of historical data about the drought indicates that, in relation to aspects of the needs of water to supply the population with drinking water and for supplying other sectors of economy, the warning state of hydrogeological drought hazard occurs when the levels below threshold persist for a period exceeding six months. If, after this period, a renewal of resources is not sufficient drought may extend or stretch in two seasons and become deeper. If, in the second hydrological year, the conditions under the threshold persist for over six months, the situation should be considered alarming. This degree of concern also arises when the observations below the threshold occur for more than one year. Due to the previously described aspects of the occurrence of groundwater it is very difficult to identify the boundary conditions for identifying a state of emergency. A possible condition for action might be when the water level remains below the threshold for three consecutive years of observations. Careful observations would then be needed on the monitoring of water intakes and their current exploitation.

\section{Acknowledgements}

The author thanks Prof. Ewa Krogulec and Prof. Maria Rosário Pereira for their constructive comments, which undoubtedly improved the quality of this manuscript.

\section{References}

Allen D.M., Mackie D. C., Wei M., 2004, Groundwater and climate change: a sensitivity analysis for the Grand Forks aquifer, southern British Columbia, Canada: Hydrogeology Journal, vol. 12(3), pp. 270-290.

Andreo B., Vias J., Duran J.J., Jimenez P., Lopez-Geta J.A., Carrasco F., 2008: Methodology for groundwater recharge assessment in carbonate aquifers: application to pilot sites in southern Spain. Hydrogeology Journal, vol. 16(5), pp. 911-925.

Apaydin, A., 2010, Response of groundwater to climate variation: fluctuations of groundwater level and well yields in the Halacli aquifer (Cankiri, Turkey): Environ Monit Assess, vol. 165, pp. 653-663.

Appleyard S., Cook T., 2009, Reassessing the management of groundwater use from sandy aquifers: acidification and base cation depletion exacerbated by drought and groundwater withdrawal on the Gnangara Mound, Western Australia: Hydrogeology Journal vol. 17, pp. 579-588.

Bochenska T., Gurwin J., Marszalek H., Poprawski L., Wasik M. 1998, Cainozoic groundwater aquifers in the Lubin-Glogów region - selected problems: Acta Univ. Wratisl. No.2109, Wroclaw, 175 pp.

Bras RL, Rodriguez-Iturbe I, 1985, Random Functions and Hydrology: Addison-Wesley, Reading, 559 pp.

Brooker P., 1979, Kriging: Engineering and Mining Journal, vol. 180, no.9, pp. 148-153.

Buczynski S., Wcislo M., 2013, Predicting climate-induced changes in groundwater resources on the basis of hydrogeological model research: Case study of the Carpathian flysch belt. Episodes vol. 36, no. 2, pp. $105-114$

Calow R.C., Robins N.S., MacDonald A.M., MacDonald M.J., Gibbs B.R., Orpen W.R.G., Mtembezeka P., Andrews A.J., Appiah S.O., 1997,
Groundwater management in drought-prone areas of Africa: Water Resource Development, v. 3(2), pp. 241-261.

Cramer H, Leadbetter MR, 1967, Stationary and Related Stochastic Processes: Sample Function Properties and their Applications: Wiley, New York.

Dai Z.J., Du J.Z., Li J.F., Chen J.Y., Zhang X.L., 2010, Groundwater discharge to the Changjiang River, China, during the drought season of 2006: effects of the extreme drought and the impoundment of the Three Gorges Dam: Hydrogeology Journal, vol. 18, pp. 359-369.

Dubicki A., Adynkiewicz-Piragas M., Zdralewicz I., 2010, Monitoring stosunków wodnych w przeksztalconym krajobrazie strefy przygranicznej (The water conditions monitoring in transformed landscape of PolishGerman borderland): Problemy Ekologii Krajobrazu, T. XXVI, pp. 161169.

Dyjor S., 1995, Rozwój kenozoiku na bloku przedsudeckim (Evolution of Cenozoic series in the Fore-Sudetic Block): Przew. 66. Zjazdu Pol. Tow. Geol., Wroclaw, pp. 29-40.

El-Kadi A. I., Tillery S., Whittier R. B., Hagedorn B., Mair A., Ha K., Koh G.W., 2014, Assessing sustainability of groundwater resources on Jeju Island, South Korea, under climate change, drought, and increased usage: Hydrogeology Journal, vol. 22, pp. 625-642.

Frankowski Z., Galkowski P., Mitrêga J., 2007: Opracowanie metodyki identyfikacji i ustalenie struktury poboru wód podziemnych dla potrzeb oceny stanu ilosciowego wód podziemnych kraju (Development of methodology for the identification and determination of the structure of groundwater use for the assessment of groundwater quantitative status of the country): Min. Srod., PIG-PIB, Warszawa.

Frankowski Z., Gakkowski P., Mitrêga J., 2009, Struktura poboru wód podziemnych w Polsce: Informator PSH (Structure of groundwater use in Poland), PIG-PIB, Warszawa.

Gurwin J., 2010, Ocena odnawialnosci struktur wodonosnych bloku przedsudeckiego. Integracja danych monitoringowych i GIS/RS z numerycznymi modelami filtracji (Renewal assessment of water-bearing structures within the Fore-Sudetic Block. Integration of monitoring and GIS/RS data with numerical flow models): Hydrogeologia Acta Univ. Wratisl. No. 3258, Wyd. U.Wr., Wroclaw, 218 pp.

Gurwin J., Lubczynski M., 2005, Modeling of complex multi-aquifer systems for groundwater resources evaluation-Swidnica study case (Poland): Hydrogeology Journal, vol. 13, No.4, pp. 627-639.

Isaaks E.H., Srivastava R.M., 1988, Spatial continuity measures for probabilistic and deterministic geostatistics: Math. Geology, vol. 20, no. 4, pp. 313-341.

Isaaks E.H., Srivastava R.M., 1989, Applied geostatistics: Oxford University Press, New York, 580 pp.

Kazimierski B., Cabalska J., Mikolajczyk A., Pilichowska-Kazimierska E., 2009, Ocena zagrozenia susza hydrogeologiczna (gruntowa) na obszarze Polski (Risk assessment of hydrogeological drought in Poland): Materialy XVIII Ogólnopolskiego Sympozjum Zintegrowanego Monitoringu Srodowiska Przyrodniczego.

Kitanidis P.K., 1997, Introduction to geostatistics. Applications in hydrogeology: Cambridge Univ. Press, New York, 249 pp.

Kondracki J., 2009, Geografia regionalna Polski (Regional geography of Poland): PWN, Warszawa, $468 \mathrm{pp}$.

Kowalczyk A., 2003, Formowanie sie zasobów wód podziemnych w utworach weglanowych triasu slasko-krakowskiego w warunkach antropopresji (Formation of groundwater resources in carbonate aquifers of the SilesianCracow Triassic under a human impact): Scientific Papers of the University of Silesia in Katowice, No. 2152, Wyd. US. Katowice, 196 pp.

Loáiciga H.A., 2003, Climate Change and Ground Water: Annals of the Association of American Geographers, 93(1), pp. 30-41.

Lorenc H. (ed.), 2005, Climate Atlas of Poland: IMGW Warszawa, 116 pp.

MacDonald A.M., Calow R.C., MacDonald D.M.J., Darling W.G., Docartaigh B.É.Ó., 2009, What impact will climate change have on rural groundwater supplies in Africa?: Hydrol. Sci. J. 54(4), pp. 691-703.

MGGP, 2010, Szczególowe wymagania, ograniczenia i priorytety dla potrzeb wdrazania planu gospodarowania wodami na obszarach dorzeczy 
(Detailed requirements, constraints, and priorities for the implementation of the management plan of the river basins): KZGW/RZGW Kraków, MGGP S.A., Kraków.

Münch Z., Conrad J., 2007, Remote sensing and GIS based determination of groundwater dependent ecosystems in the Western Cape, South Africa: Hydrogeology Journal, vol. 15, pp. 19-28.

Okkonen J., Jyrkama M., Kløve B., 2010, A conceptual approach for assessing the impact of climate change on groundwater and related surface waters in cold regions (Finland): Hydrogeology Journal, vol. 18(2), pp. 429439.

Paczynski B., Sadurski A. (ed.), 2007, Hydrogeologia regionalna Polski (Regional hydrogeology of Poland). T. 1, 2: Wyd. PIG, Warszawa, 542 pp.

Peters E., 2003, Propagation of drought through groundwater systems. Illustrated in the Pang (UK) and Upper-Guadiana (ES) catchments: Dissertation Wageningen Universiteit, Wageningen 2003, 203 pp.

Radfar M., Van Camp M., Walraevens K., 2013, Drought impacts on longterm hydrodynamic behavior of groundwater in the tertiary-quaternary aquifer system of Shahrekord Plain, Iran: Environmental Earth Science, v. 70 , pp. $927-942$.

Radhakrishnan, N., Elango, L., 2011, Study of influence of terrain and climatic factors on groundwater level fluctuation in a minor river basin using GIS: Geo-spatial Information Science, v. 14, no. 3, pp. 190-197.

Regional Water Management Board (RWMB), 2007, Report of significant problems of water management: RWMB Wroclaw.

Rice S.O., 1954, Mathematical analysis of random noise: In Wax N (ed) Selected Papers on Noise and Stochastic Processes, Dover, New York. $133 / 294$.

Rutulis M., 1987, Groundwater drought sensitivity of Southern Manitoba: Paper presented at the Canadian Water Resources Association 40 Annual Conference, 15-18 June 1987, Winnepeg, MB.

Shahid S, Hazarika M.K., 2010, Groundwater Drought in the Northwestern Districts of Bangladesh: Water Resour Manage, 24, pp. 1989-2006.

Stasko S., 1992, Wody podziemne w weglanowych utworach triasu opolskiego (Groundwater in carbonate triassic rocks in Opole region, SW Poland):
Acta Univ. Wratisl. No. 1407, Wyd. U.Wr., Wroclaw, 74 pp.

Stasko S., Chudy K., Gurwin J., Olichwer T., Tarka R., Wasik M., Michniewicz M., Wojtkowiak A., Sobol L., Kielczawa J., Nowacki F., Sliwka R., Firlit G., Tyralski M., Wyszowska I., 2005, Charakterystyka zmian polozenia zwierciadla wód podziemnych w regionie wodnym Odry Srodkowej (Characteristic of the groundwater table fluctuations in the Middle Odra River region) - for RWMB Wroclaw: ING UWr., PIG-PIB \& Proxima S.A.

Stasko S., Olichwer T., Tarka R., 2008, Susza hydrogeologiczna w Sudetach (Hydrogeological drought in Sudety Mts.): Zarzadzanie zasobami wodnymi w dorzeczu Odry-2008, wyd. RZGW Wroclaw

Stolarska M., Sowinska K., Absalon D., Gurwin J., Wasik M., 2012, Projekt planu przeciwdzialania skutkom suszy (The draft plan counteract the effects of drought): PectoreEco, Gliwice.

Tallaksen, L. M., van Lanen, H. A. J., Eds., 2004, Hydrological drought, Processes and estimation methods for streamflow and groundwater: Development in water science 48, Elsevier, Netherlands, 579 pp.

Tarka R., Stasko S., 2010, Wahania zwierciadla wód podziemnych jako odzwierciedlenie ekstremalnych sytuacji pogodowych (Fluctuations in groundwater levels as a reflection of extreme weather situations): Wyjatkowe zdarzenia przyrodnicze na Dolnym Elasku i ich skutki (ed. P. Migoñ), Wyd. UWr., pp. 241-255

Villholth K.G, Tøttrup C., Stendel M., Maherry A., 2013, Integrated mapping of groundwater drought risk in the Southern African Development Community (SADC) region: Hydrogeology Journal vol. 22, pp. 625642 .

Wojtkowiak A., Biel A., Chudzik L., Czerski M., Kielczawa J., Krawczyk A., Michniewicz M., Zawistowski K., 2008, Stan wykorzystania wód przeznaczonych do zaopatrzenia ludnosci w wode do spozycia $\mathrm{w}$ jednolitych czêœciach wód na obszarze RZGW we Wroclawiu - Etap II (Condition of use of water for public supply with drinking water in water bodies in the area of the RWMB in Wroclaw): PIG-PIB Wroclaw.

Woldeamlak, S.T., Batelaan, O., and De Smedt, F., 2007, Effect of climate change on the groundwater system in the Grote-Nete catchment, Belgium: Hydrogeology Journal, v. 15, pp. 891-901.

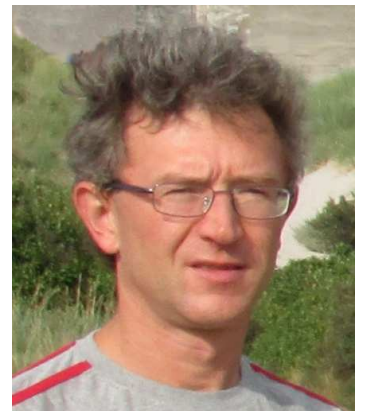

Jacek Gurwin is an assistant professor at the Univesrsity of Wroclaw, Poland (Ph.D. with habilitation). A hydrogeological and environmental research activity mostly evolves to numerical modelling of groundwater flow and groundwater resources evaluations considering systems of management and sustainable use of water within catchment, basin or other complex regional hydrogeological system/unit. Research practice is focused on using and integration of environmental monitoring data and geoinformatic systems with advanced numerical modelling tools including unsaturated zone and mass transport issues. 